\title{
Exploitation of FTA Cartridges for the Sampling, Long-Term Storage, and DNA-Based Analyses of Plant-Parasitic Nematodes
}

\author{
Martin Marek, Miloslav Zouhar, Ondřej Douda, Marie Maňasová, and Pavel Ryšánek
}

First, second, fourth, and fifth authors: Czech University of Life Sciences (CULS) Prague, Faculty of Agrobiology, Food and Natural Resources, Department of Plant Protection, Kamycká 129, 16521 Prague 6-Suchdol, The Czech Republic; and third author: Crop Research Institute, Division of Plant Health, Department of Entomology, Drnovská 507, 16106 Prague 6-Ruzyňe, The Czech Republic. Accepted for publication 19 September 2013

\begin{abstract}
Marek, M., Zouhar, M., Douda, O., Maňasová, M., and Ryšánek, P. 2014. Exploitation of FTA cartridges for the sampling, long-term storage, and DNA-based analyses of plant-parasitic nematodes. Phytopathology 104:306-312.

The use of DNA-based analyses in molecular plant nematology research has dramatically increased over recent decades. Therefore, the development and adaptation of simple, robust, and cost-effective DNA purification procedures are required to address these contemporary challenges. The solid-phase-based approach developed by Flinders Technology Associates (FTA) has been shown to be a powerful technology for the preparation of DNA from different biological materials, including blood, saliva, plant tissues, and various human and plant microbial pathogens. In this work, we demonstrate, for the first time, that this FTA-based technology is a valuable, low-cost, and time-saving approach for the sampling, long-term archiving, and molecular analysis of plant-parasitic nematodes. Despite the complex structure and anatomical organization of

the multicellular bodies of nematodes, we report the successful and reliable DNA-based analysis of nematode high-copy and low-copy genes using the FTA technology. This was achieved by applying nematodes to the FTA cards either in the form of a suspension of individuals, as intact or pestle-crushed nematodes, or by the direct mechanical printing of nematode-infested plant tissues. We further demonstrate that the FTA method is also suitable for the so-called "one-nematode-assay", in which the target DNA is typically analyzed from a single individual nematode. More surprisingly, a time-course experiment showed that nematode DNA can be detected specifically in the FTA-captured samples many years after initial sampling occurs. Collectively, our data clearly demonstrate the applicability and the robustness of this FTA-based approach for molecular research and diagnostics concerning phytonematodes; this research includes economically important species such as the stem nematode (Ditylenchus dipsaci), the sugar beet nematode (Heterodera schachtii), and the Northern root-knot nematode (Meloidogyne hapla).
\end{abstract}

DNA-based analyses in molecular plant nematology research have dramatically increased over previous decades $(19,21,23,24)$. These activities are mainly focused on fundamental investigations concerning the biology of nematodes at the molecular and cellular levels (11) as well as practical applications concerning phytosanitary diagnostics $(10,16)$ and plant breeding or transgenic technologies $(8,14,25)$. To effectively address these contemporary challenges in molecular plant nematology, the development and adaptation of simple, rapid, and cost-effective DNA purification procedures are needed.

The matrix-based approach developed by Flinders Technology Associates (FTA) (Whatman, Kent, UK) is a powerful technology for the preparation of DNA from different biological materials, including blood, saliva, plant tissues, and various human and plant pathogens $(1,4,6,9,13,20)$. This solid-phase format enables out-of-lab sampling and greatly simplifies DNA archiving and purification. Unlike other conventional DNA purification methods that use various organic chemicals (e.g., phenol and chloroform) (17), the FTA-based approach uses only nontoxic aqueous solutions. All of the steps during FTA-based archiving and DNA preparation are carried out at room temperature, which signifi-

Corresponding author: M. Marek;

E-mail address: autographa.californica@gmail.com

* The $\boldsymbol{e}$-Xtra logo stands for "electronic extra" and indicates that Figure 1 appears in color online.

http://dx.doi.org/10.1094/PHYTO-03-13-0067-R

(C) 2014 The American Phytopathological Society cantly reduces the expense and is environmentally friendly. The DNA captured on the FTA cartridges can be used in various polymerase chain reaction (PCR)-based protocols, such as markerbased selection, molecular diagnostics, phylogenetic studies, and transgene detection $(2,13,20,22)$. There is no evidence thus far concerning the feasibility of this FTA-based technology in the sampling and analysis of plant-parasitic nematodes, which are eukaryotic multicellular organisms that infect plants.

In the current report, we demonstrate that the FTA-based technology is fully applicable to the collection, long-term archiving, and molecular analysis of plant-parasitic nematodes. Despite the complex structural and anatomical organization of multicellular nematode bodies, we show the successful and highly reliable DNA-based analysis of target high-copy and low-copy genes using the FTA technology.

\section{MATERIALS AND METHODS}

Nematode species. The following three biologically different species of plant-parasitic nematodes were analyzed in this report: the stem nematode (Ditylenchus dipsaci) (17), the sugar beet nematode (Heterodera schachtii), and the Northern root-knot nematode (Meloidogyne hapla) (27). Detailed information concerning the geographic origins of the nematodes used, their host preferences, and the sources of the nematodes are listed in Table 1.

FTA-based sampling, archiving, and DNA preparation. To capture the nematode specimens on the FTA matrix, individual intact or pestle-crushed nematodes were dripped onto the surface of the FTA cards (Whatman). The direct mechanical printing of 
nematode-infested plant tissues on the FTA cards with the help of a hand tool was also tested. After application of the samples, the FTA cards were air dried and stored at room temperature for the indicated durations. A schematic overview of the nematode sampling methods used for the FTA-based approach is illustrated in Figure 1.

A sterile perforator (Harris Uni-Core device; Whatman) with a diameter of $3 \mathrm{~mm}$ was used to punch a disk from the FTA card where the specimen had been previously applied (Fig. 1H). The perforator was cleaned as described in the manufacturer's protocol to prevent cross-contamination. For each PCR test, one disk was treated. Briefly, the disk was washed with $200 \mu$ of a FTA purification solution (Whatman) three times for $5 \mathrm{~min}$. The disk was then washed with $200 \mu \mathrm{l}$ of Tris-EDTA (TE) buffer $(10 \mathrm{mM}$ Tris and $0.5 \mathrm{mM}$ EDTA [pH 8.0]) twice for $5 \mathrm{~min}$ and air dried. In the last step, the disk was directly used as a template for the PCR reaction; this was carried out in the same tube in which all of the previous purification steps occurred. All purification steps were carried out at room temperature.

Conventional DNA preparation procedure. For comparative testing, total genomic DNA was also extracted from the nematodes following modified methods that have been previously de-

TABLE 1. Nematode species used in this study

\begin{tabular}{|c|c|c|c|}
\hline Nematode species & Host (common name) & Country of origin & Source (reference) \\
\hline Ditylenchus dipsaci & Cichorium intybus (leaf chicory) & Slovenia & G. Urek (17) \\
\hline Heterodera schachtii & Beta vulgaris (sugar beet) & Czech Republic & M. Zouhar \\
\hline Meloidogyne hapla & Daucus carota (carrot) & Czech Republic & M. Zouhar (27) \\
\hline
\end{tabular}

A

1. Sample application

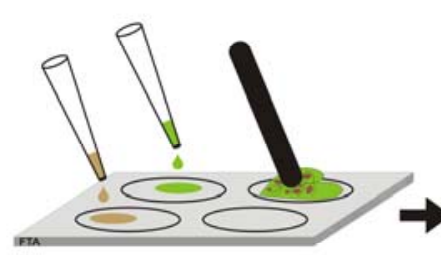

2. Disk removal

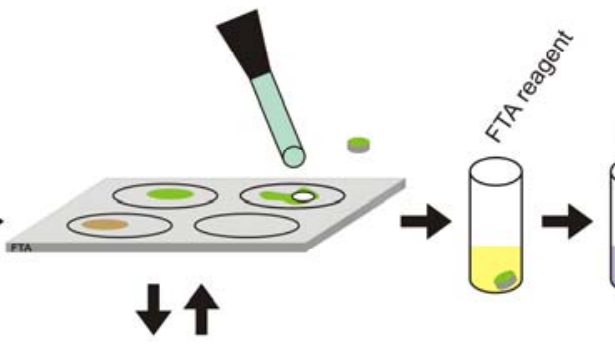

$\downarrow \uparrow$

5. Long-term archiving
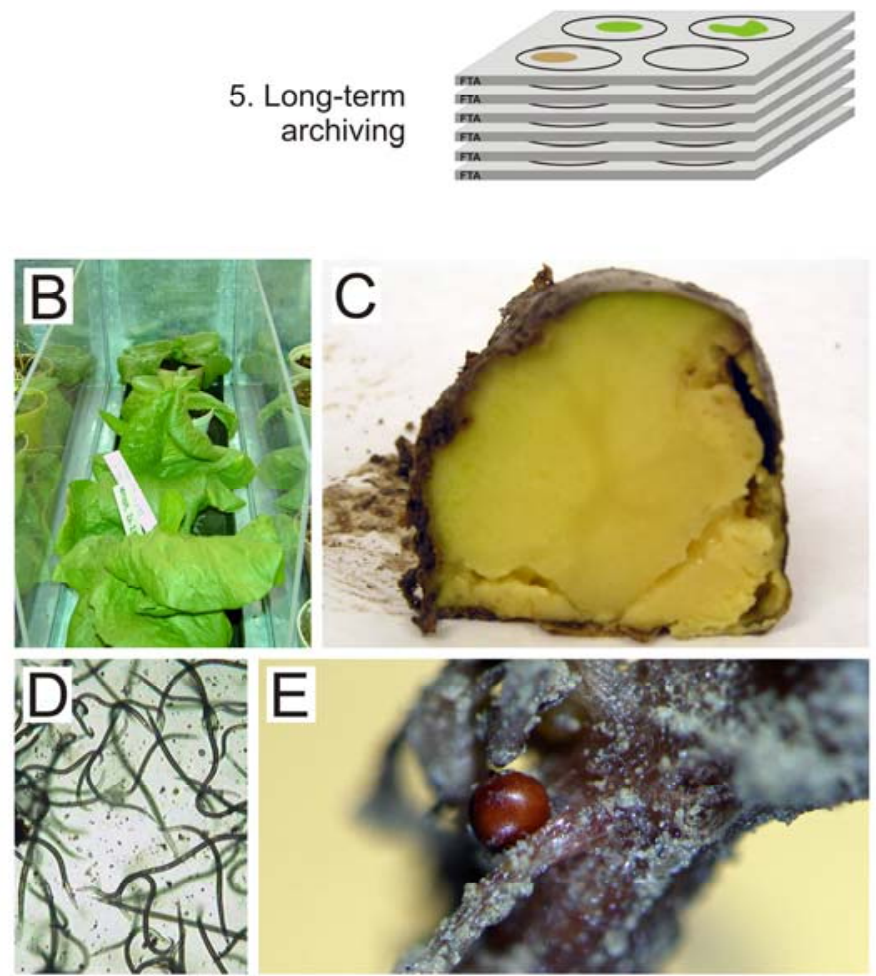
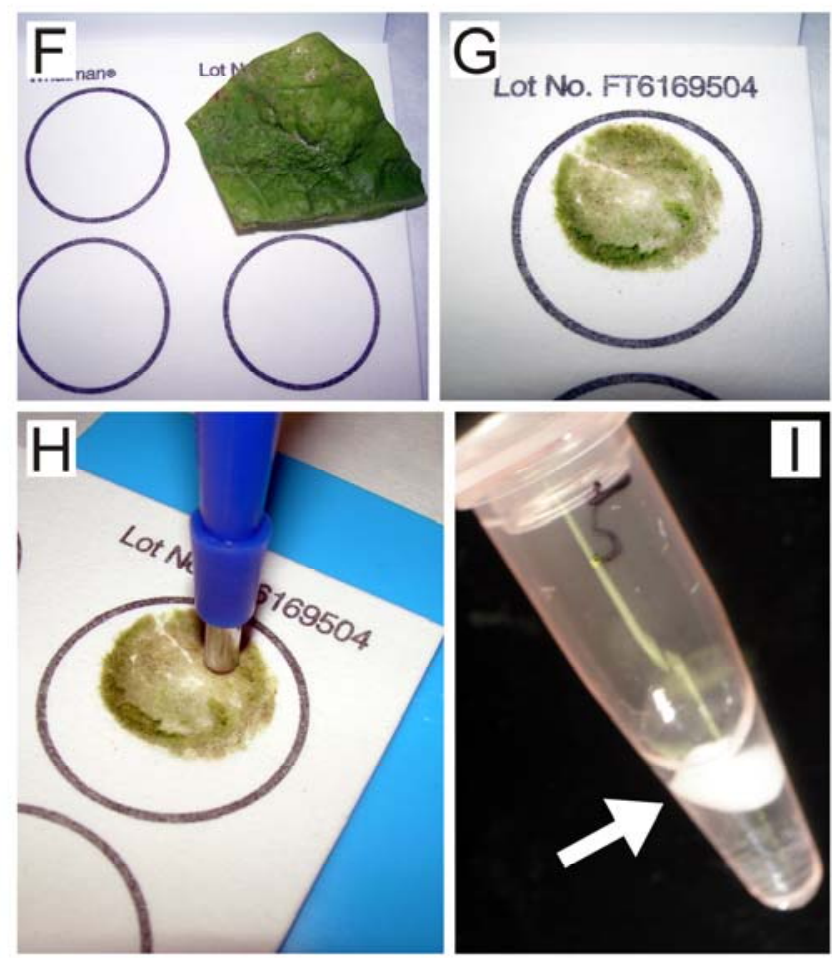

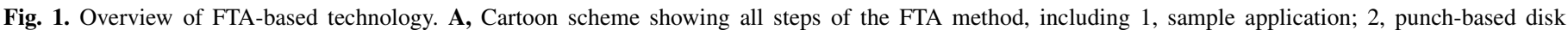

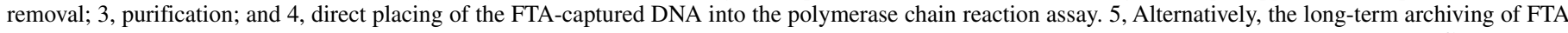

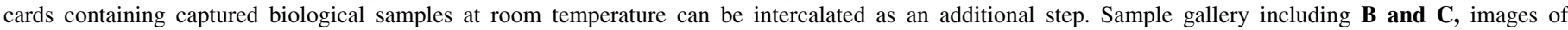

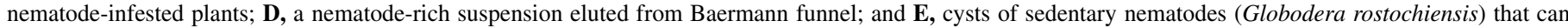

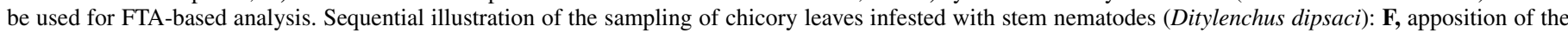

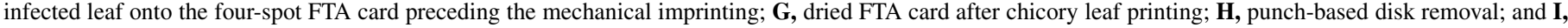

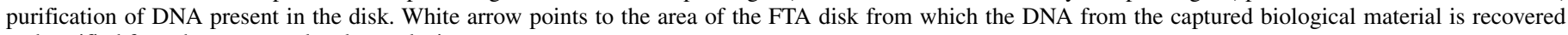
and purified for subsequent molecular analysis. 
scribed (5,15-17). Briefly, the desired amount of nematodes was transferred into a sterile $1.5-\mathrm{ml}$ tube containing $50 \mu \mathrm{l}$ of lysis buffer (100 mM Tris-HCl [pH 8.0], 5 mM EDTA, $200 \mathrm{mM} \mathrm{NaCl}$, $0.2 \%$ sodium dodecyl sulfate, and proteinase $\mathrm{K}$ at $4 \mu \mathrm{g} / \mathrm{ml}$ ). The mixture was incubated for $1 \mathrm{~h}$ at $55^{\circ} \mathrm{C}$. The proteinase $\mathrm{K}$ was then denatured for $5 \mathrm{~min}$ at $85^{\circ} \mathrm{C}$. The DNA was extracted using phenol-chloroform extraction. Finally, the DNA was precipitated with an equal volume of ice-cooled isopropanol and washed with $80 \%$ ethanol. The resulting DNA pellet was resuspended in $20 \mu \mathrm{l}$ of TE buffer (10 mM Tris and $0.5 \mathrm{mM}$ EDTA [pH 8.0]). The DNA stocks were stored at $-20^{\circ} \mathrm{C}$.

PCR amplification. The universal primers S18 and S26 (Table 2) were used to amplify the nuclear high-copy ribosomal DNA (rDNA) gene region encompassing the $3^{\prime}$ end of $18 \mathrm{~S}$ rRNA; the complete sequences of internal transcribed spacer (ITS)1, 5.8S rRNA, and ITS2; and the $5^{\prime}$ end of the 28S rRNA from $D$. dipsaci. Additionally, the D. dipsaci-specific primers PF1 and PR1 (17) (Table 2) were also used to amplify the high-copy ITSrDNA region. The primers DIT5F and DIT5R (26) (Table 2) were used for the amplification of a low-copy sequence-characterized amplified region (SCAR)-derived DNA marker. To amplify the host chloroplast gene encoding ribulose-1,5-(bis)-phosphate-carboxylase (RuBisCO), the primers Rbcl-F and Rbcl-R (16) (Table 2) were used. For the specific amplification of the $H$. schachtii ITS-rDNA region, the primers HSF2 and HSR2 (Table 2) were designed. The previously described primers MHOF and MH1R (27) (Table 2) were used for the detection of M. hapla.

The PCR reactions were performed in 0.2-ml tubes with a final reaction mixture volume of $50 \mu \mathrm{l}$, which contained $5.00 \mu \mathrm{l}$ of a $10 \times$ buffer for the DNA polymerase (Fermentas, Vilnius, Lithuania), $6 \mu \mathrm{l}$ of $25 \mathrm{mM} \mathrm{MgCl}$ (Fermentas), $0.5 \mu \mathrm{l}$ of $25 \mathrm{mM}$ dNTP (Fermentas), $0.5 \mu \mathrm{l}$ of the oligonucleotide primers $(50 \mu \mathrm{M})$, $0.8 \mu \mathrm{l}(2.5 \mathrm{U})$ of Taq DNA polymerase (Fermentas), and one 3-mm DNA-containing FTA disk or $2.00 \mu \mathrm{l}$ of DNA (100 ng/ $\mu \mathrm{l})$. The PCR protocol used was as follows: an initial denaturation at $95^{\circ} \mathrm{C}$ for $2 \mathrm{~min}$, followed by 36 cycles $\left(94^{\circ} \mathrm{C}\right.$ for $1 \mathrm{~min}, 58$ to $60^{\circ} \mathrm{C}$ for $30 \mathrm{~s}$, and $72^{\circ} \mathrm{C}$ for $1 \mathrm{~min}$ ) and a final extension at $72^{\circ} \mathrm{C}$ for $7 \mathrm{~min}$.

DNA electrophoresis. The generated PCR products were separated by electrophoresis in a $1.2 \%$ (wt/vol) agarose gel with $1 \times$ Tris-borate-EDTA buffer. The gels were stained with ethidium bromide and visualized under UV light. The lengths of the DNA fragments were estimated by comparison with the MassRuler Low Range 100-bp DNA ladder (Fermentas).

Evaluation of PCR reliability. The reliability of the PCR tests was calculated according to the following formula: percent positive assays $=$ (number of positive assays/total number of assays $) \times$ 100. A positive assay was a PCR test in which a DNA band of an expected length was detected by DNA electrophoresis and confirmed by DNA sequencing.

\section{RESULTS}

FTA-based analysis of the stem nematode $D$. dipsaci. To prove the applicability of FTA technology in molecular plant nematology, the stem nematode $D$. dipsaci was chosen as a model organism for pilot testing. The first assays were carried out with a suspension of individual nematodes eluted from naturally infested chicory leafs using a Baermann funnel technique (Fig. 1C). Different numbers of nematodes were dripped onto the FTA matrix, which was subsequently air dried and kept at room temperature for a 1-month period. Afterward, 3-mm discs were punched from the FTA matrix and the DNA was purified according to the manufacturer's recommendations. Finally, the species-specific primers PF1 and PR2 (17) were used to amplify a target ITS-rDNA gene fragment. We could reliably detect specific DNA fragments of an expected length of $327 \mathrm{bp}$ (Fig. 2A). When only 10 nematode individuals were loaded onto the FTA cards, a specific DNA band (327 bp) was detected in all independent assays; this demonstrates the high sensitivity and reproducibility of the FTA-based strategy.

Our results show that the FTA technology is fully applicable to the molecular analysis of $D$. dipsaci to the same extent as wellestablished conventional (standard) methods (17) that use organic chemicals. In our comparative analyses, we gained similar reliability in the PCR tests in both the FTA-based and standard procedures (Fig. 2). The major benefit of the FTA-based approach is the reduced time needed for the preparation of the DNA. Whereas the conventional and organic chemical-based method required several hours, the FTA-based strategy took dozens of minutes to obtain PCR-ready DNA. This leads to significant time savings when the FTA technology is used.

Sampling and analysis of other plant-parasitic nematodes by the FTA technology. To prove the applicability of the FTA technology for other plant-parasitic nematodes, we tested the following two nematode species: the sugar beet nematode, $H$. schachtii, and the Northern root-knot nematode, M. hapla. The FTA-based sampling and the subsequent molecular analysis of these species also resulted in successful PCR amplification of the target DNA regions (Figs. 3 and 4). In the case of $H$. schachtii, the FTA strategy provided results similar to the standard DNA purification method. We noted that the FTA technology resulted in a higher yield of PCR products when a low number of nematodes were used in the assays (Fig. 3).

During $M$. hapla testing, the FTA technology appeared to be significantly more efficient than the standard DNA purification procedure, especially when low numbers of nematodes were used in the assays (Fig. 4). Although both the FTA and standard method resulted in the amplification of sufficient quantities of target DNA when either 50 or 100 nematodes were used, the standard method failed to achieve this when only 10 nematodes were used (Fig. 4B). The FTA technology consistently resulted in

TABLE 2. Polymerase chain reaction (PCR) primers used in this study

\begin{tabular}{|c|c|c|c|c|c|c|}
\hline Target organism & Primer name & Sequence $\left(5^{\prime}-3^{\prime}\right)$ & Sense $^{\mathrm{a}}$ & PCR product size (bp) & Target gene ${ }^{b}$ & Reference \\
\hline Ditylenchus dipsaci & PF1 & AACGGCTCTGTTGGCTTCTAT & $\mathrm{F}$ & 327 & ITS-rDNA & 17 \\
\hline D. dipsaci & PR1 & ATTTACGACCCTGAGCCAGAT & $\mathrm{R}$ & 327 & ITS-rDNA & 17 \\
\hline D. dipsaci & S 18 & TTGATTAGGTCCCTGCCCTTT & $\mathrm{F}$ & 967 & ITS-rDNA & 17 \\
\hline D. dipsaci & S26 & TTTCACTCGCCGTTACTAAGG & $\mathrm{R}$ & 967 & ITS-rDNA & 17 \\
\hline D. dipsaci & DIT5F & GAAAACCAAAGAGGCCGTAAC & $\mathrm{F}$ & 245 & SCAR marker & 26 \\
\hline D. dipsaci & DIT5R & ACCTGATTCTGTACGGTGCAA & $\mathrm{R}$ & 245 & SCAR marker & 26 \\
\hline Heterodera schachtii & HSF2 & CACATGTGAAAGCCTGTGGA & $\mathrm{F}$ & 621 & ITS-rDNA & This study \\
\hline H. schachtii & HSR2 & GCCGAGCTGAGCAAGTAAAG & $\mathrm{R}$ & 621 & ITS-rDNA & This study \\
\hline Meloidogyne hapla & $\mathrm{MHOF}$ & CAGGCCCTTCCAGCTAAAGA & $\mathrm{F}$ & 960 & ITS-rDNA & 27 \\
\hline M. hapla & MH1R & CTTCGTTGGGGAACTGAAGA & $\mathrm{R}$ & 960 & ITS-rDNA & 27 \\
\hline Cichorium intybus & Rbcl-F & AGTCATGCATTACGATCCGAA & $\mathrm{F}$ & 582 & RuBisCO gene & 16 \\
\hline C. intybus & Rbcl-R & CCAGTCTTGATCGTTACAAA & $\mathrm{R}$ & 582 & RuBisCO gene & 16 \\
\hline
\end{tabular}

${ }^{\mathrm{a}} \mathrm{F}=$ forward and $\mathrm{R}=$ reverse.

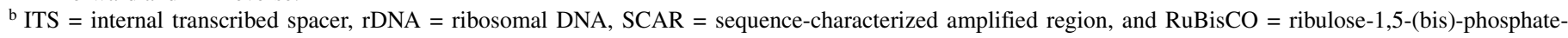
carboxylase. 
the amplification of sufficient amounts of amplified PCR product (Fig. 4A). Collectively, our data show that the FTA technology can be used for the sampling and molecular analysis of phytoparasitic nematodes from the genera Heterodera and Meloidogyne.

FTA cards are capable of capturing nematode DNA directly from nematode-infested plant tissues. The elution of plant- parasitic nematodes using the Baermann funnel method is a timeconsuming procedure. Therefore, we decided to assess the direct printing of nematode-infested plant tissues onto the FTA matrix. We placed $D$. dipsaci-infested chicory leaves onto the FTA matrix and mechanically printed them (Fig. 1). Again, the FTA matrix was air dried after sample application and stored at room tem-

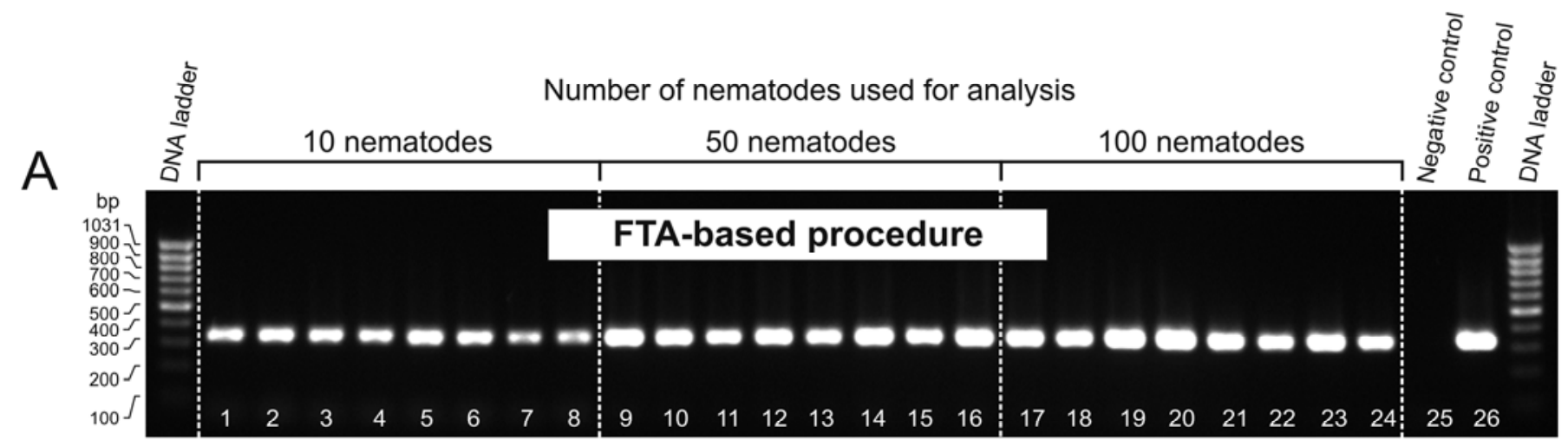

B

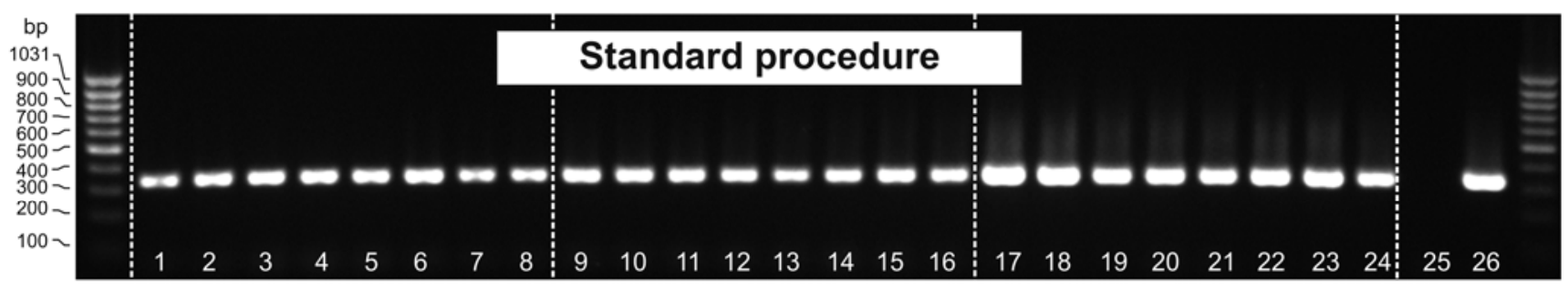

Fig. 2. FTA-based analysis of the stem nematode Ditylenchus dipsaci. Polymerase chain reaction (PCR)-based detection of a high-copy internal transcribed spacer ribosomal DNA target gene using A, the FTA technology and B, the standard DNA purification procedure. The indicated numbers of nematodes (lines 1 to 8 , 10 nematodes/assay; lines 9 to 16,50 nematodes/assay; and lines 17 to 24, 100 nematodes/assay) were used for the analyses, as explained in the top legend. The expected length of the DNA fragment amplified using the species-specific primers PF1 and PR1 was 327 bp. Lanes 25 and 26 are PCR controls, where either sterile distilled water (negative control) or well-defined D. dipsaci genomic DNA (positive control) were used. The DNA ladder used was the GeneRuler 100-bp DNA ladder (Fermentas).

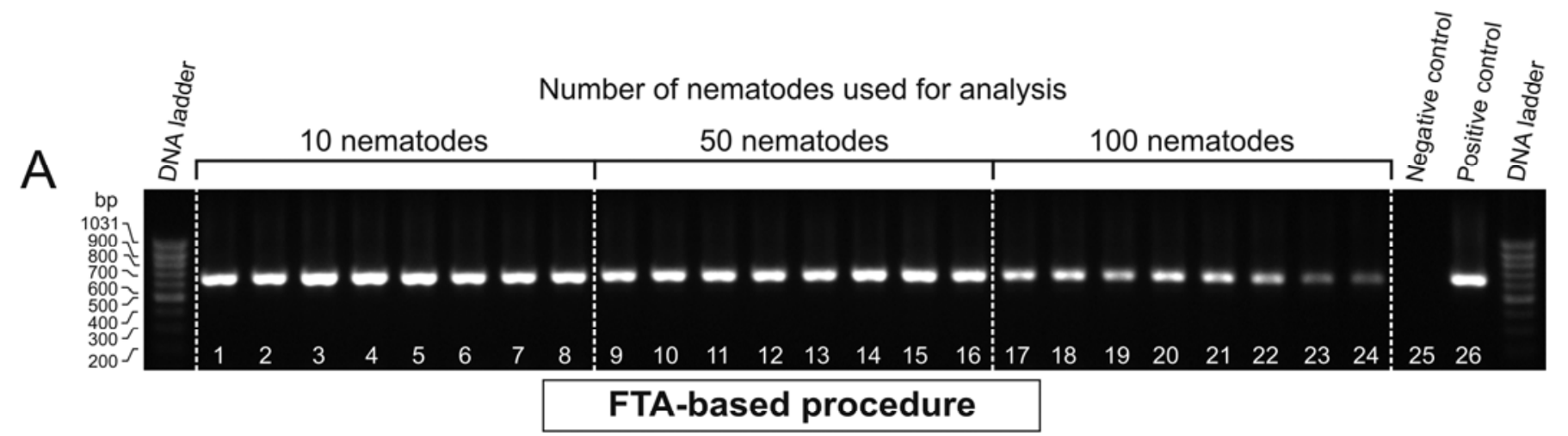

B

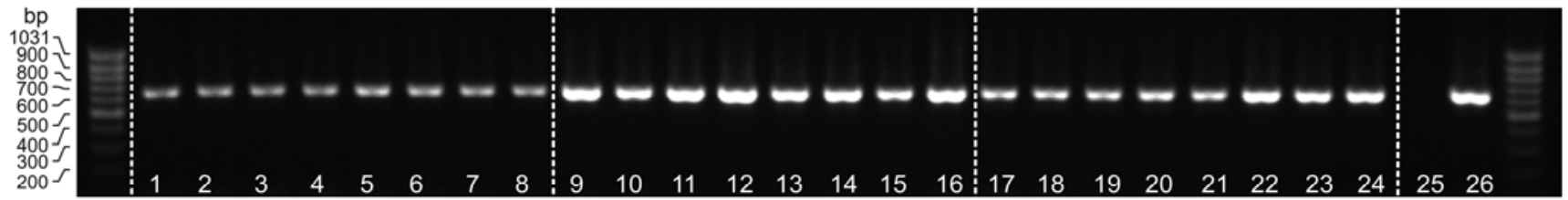

Standard procedure

Fig. 3. FTA-based analysis of the sugar beet nematode Heterodera schachtii. Polymerase chain reaction (PCR)-based detection of the high-copy internal transcribed spacer ribosomal DNA target gene using A, the FTA technology and $\mathbf{B}$, the standard DNA purification procedure. The indicated numbers of nematodes (lines 1 to 8, 10 nematodes/assay; lines 9 to 16, 50 nematodes/assay; and lines 17 to 24, 100 nematodes/assay) were used for analyses, as explained in the top legend. The expected length of the DNA fragment amplified with the species-specific primers HSF-2 and HSR-2 was 621 bp. Lanes 25 and 26 are PCR controls, where either sterile distilled water (negative control) or well-defined H. schachtii genomic DNA (positive control) were used. The DNA ladder used was the GeneRuler 100-bp DNA ladder (Fermentas). 
perature for a 1-month period. The nematode DNA was then prepared according to the above-mentioned protocol and amplified by PCR. We could amplify the high-copy ITS-rDNA gene with similar reliability to the conventional and organic chemical-based DNA purification procedures (Fig. 5A). Along with the nematode-specific DNA, we also successfully amplified the host plant gene encoding RuBisCO. These results demonstrate that the multiplex PCR setup can be used in combination with the FTA technology (Fig. 2C).

It is widely known $(7,18)$ that multiple copies of rDNA citrons occur in eukaryotic genomes, which significantly facilitates PCR amplification. For this reason, we investigated whether a nematode low-copy gene could also be detected using the FTA-based approach. To test this, we chose a previously identified $D$. dipsaci SCAR-derived marker (26). Surprisingly, we demonstrated the successful PCR amplification of this target SCAR marker using the FTA method. More importantly, the FTA-based analysis of this low-copy gene was more consistent than the conventional DNA purification procedure, as measured by the reliability of the PCR assays (Fig. 5B). Together, our data prove that the FTAbased technology greatly simplifies the processes of sampling and the molecular analysis of endoparasitic phytonematodes directly from nematode-infested plant tissues.

A single-nematode analysis using FTA. In nematology laboratories, there is often a need to analyze DNA from a limited number of nematodes. Cases in which only one nematode is available for an analysis are not exceptional. In such cases, the socalled "single-nematode assay" is used; a single nematode is usually crushed with a hand pestle and its homogenate is directly subjected to PCR amplification. For this reason, we were curious whether the FTA technology could be used to address these tasks. We loaded one, two, and five $H$. schachtii nematodes, which were mechanically crushed using a hand pestle, onto FTA cards. Subsequent PCR reactions demonstrated that the FTA-based strategy can efficiently capture and provide a sufficient amount of DNA for PCR amplification from a single nematode (Fig. 6A).

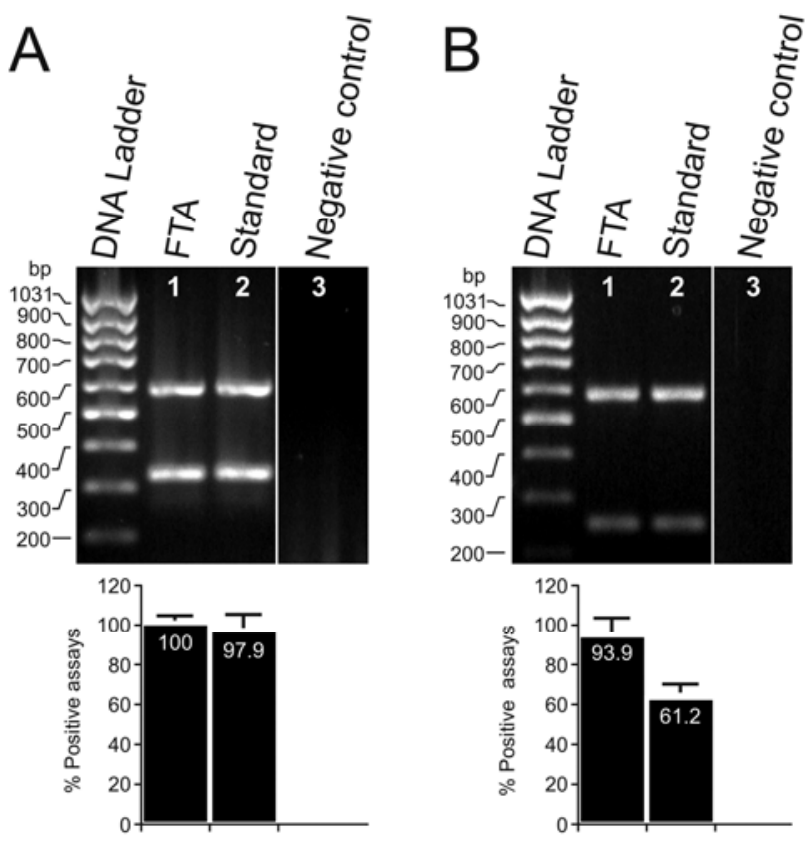

Fig. 5. Polymerase chain reaction (PCR)-based amplification of the A, highcopy and $\mathbf{B}$, low-copy nematode gene from naturally nematode-infested plant tissues. Comparison between the FTA-based technology (line 1) and the standard DNA purification procedure (line 2). For the FTA analysis, Ditylenchus dipsaci-infested chicory leaves were mechanically printed onto the FTA matrix. A region of the high-copy gene internal transcribed spacer ribosomal DNA was amplified (327 bp), while the sequence-characterized amplified region-derived marker (245 bp) was used as a low-copy gene target. The host-specific gene ribulose-1,5-(bis)-phosphate-carboxylase was used as an internal control (the expected length the plant DNA fragment is $582 \mathrm{bp}$ ). Sterile distilled water served as a negative control in all PCR assays (line 3). The DNA ladder used was the GeneRuler 100-bp DNA ladder (Fermentas). The lower graphs show the percentage $(\%)$ of positive PCR assays $(n=34)$. Results of three independent assays, with error bars representing the standard deviations, are shown.

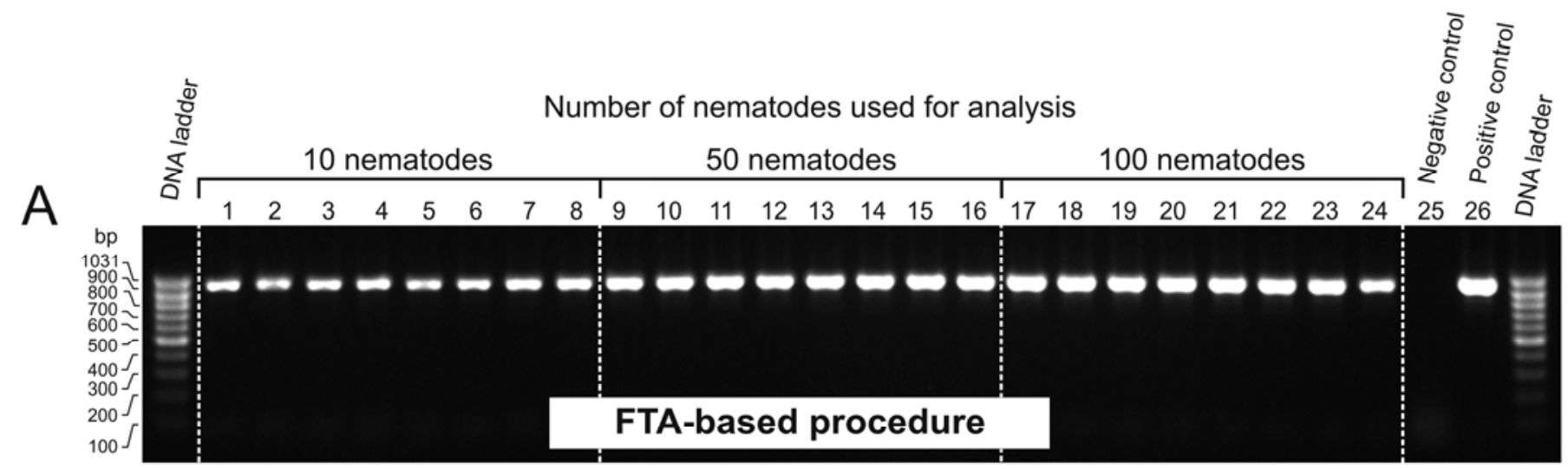

B

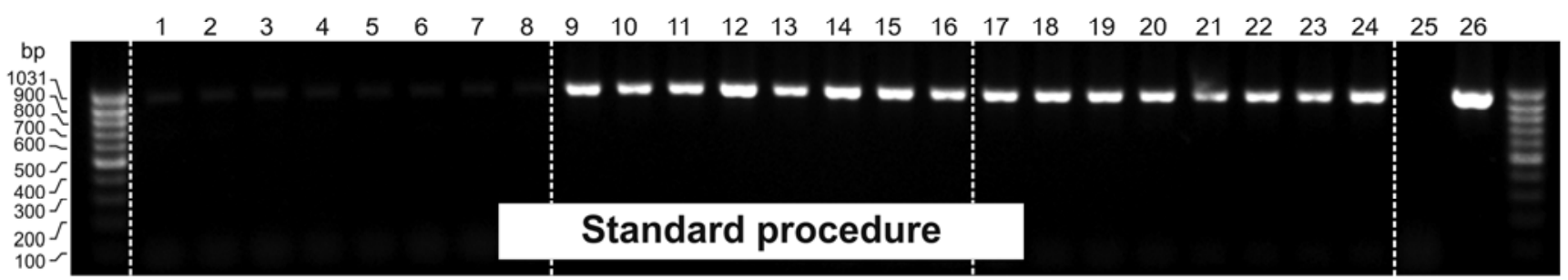

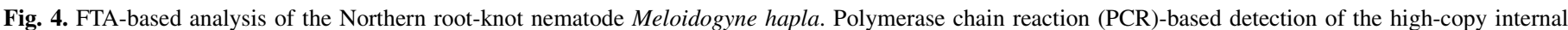

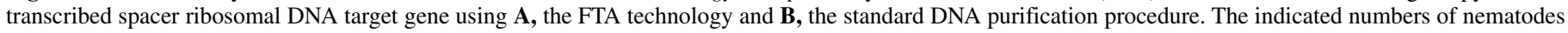

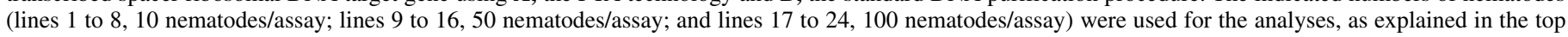

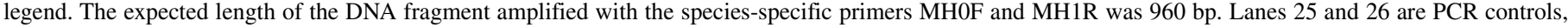

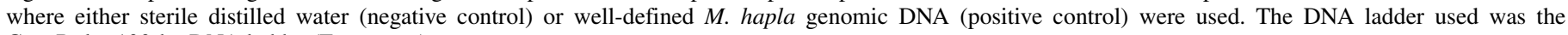
GeneRuler 100-bp DNA ladder (Fermentas). 
The advantage of such an approach is that DNA from a single nematode can be captured onto the FTA matrix and stored at room temperature for a long-term period, and DNA from this matrix may be analyzed again in the future if necessary.

How long can nematodes be archived on the FTA cards? How long biological samples can be safely stored on the FTA cards without an observable loss of DNA quality must be determined. To address this, we printed naturally $D$. dipsaciinfested chicory leaves onto the FTA card. The short time-course experiments showed that PCR-ready DNA can be routinely and reliably prepared from FTA-captured nematodes after 1 year of storage at room temperature (data not shown). Our long-term experiment, in which FTA cards loaded with $D$. dipsaci specimens were stored for 7 years at room temperature, demonstrated that nematode DNA can be specifically detected even after lengthy storage (Fig. 6B). High-copy genes such as ITS-rDNA (17) and the low-copy SCAR marker (26) were successfully detected (Fig. 4). Therefore, our data demonstrate the applicability of FTA technology for the long-term and cost-effective archiving of plant-parasitic nematodes, which can be highly valuable for diagnostic laboratories or in long-standing plant breeding processes.

\section{DISCUSSION}

In the current article, we tested the FTA-based technology for the sampling, long-term archiving, and the molecular analysis of three representative species of plant-parasitic nematodes; the species tested were $D$. dipsaci, $H$. schachtii, and $M$. hapla. We demonstrated that the FTA technology is a highly promising tool for the above-mentioned purposes, as clearly demonstrated in Figures 2 to 6 .

There have been many studies thus far $(1,2,9,13,22)$ demonstrating the applicability of the FTA-based technology for the sampling and molecular analysis of different biological materials. In general, the FTA cards are made of a chemically treated solid phase where the biological tissues and cells are instantly lysed and DNA is captured within the matrix. The FTA cards are coated (or impregnated) with a patented chemical formula that denatures proteins, including damaging nucleases (www.whatman.com).
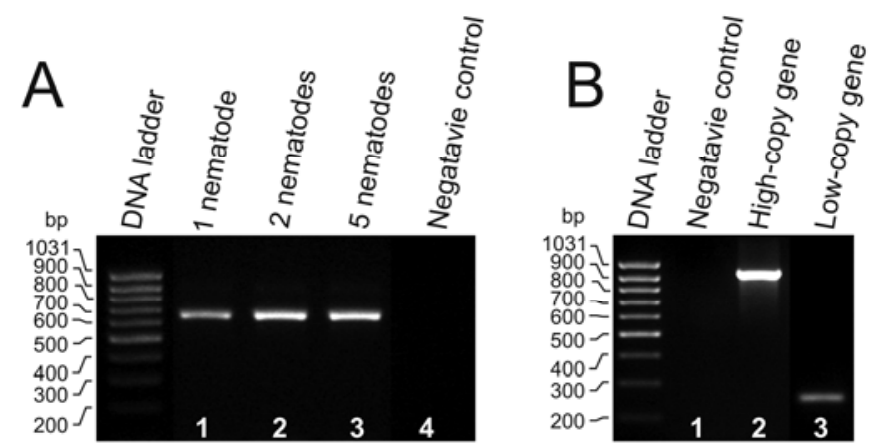

Fig. 6. Sensitivity of detection and long-term storage of FTA-captured nematode DNA. A, Polymerase chain reaction (PCR)-based detection of Heterodera schachtii DNA where only one nematode (line 1), two nematodes (line 2 ), or five nematodes (line 3 ) were loaded onto FTA discs. Sterile distilled water served as a negative control in the PCR assay (line 4). The expected length of the DNA fragment that was amplified with the species-specific primers HSF-2 and HSR-2 was 621 bp. B, Amplification of the high-copy internal transcribed spacer ribosomal DNA (ITS-rDNA) (line 2) and the lowcopy sequence-characterized amplified region (SCAR)-derived (line 3) Ditylenchus dipsaci genes. Specimens were applied to the FTA matrix by the mechanical printing of naturally infested chicory leaves. The FTA cards were then stored at room temperature for 7 years prior to molecular analysis. Sterile distilled water served as negative control in the PCR assays (line 1). The ITSrDNA region served as a high-copy gene (967 bp), while the SCAR-derived marker (245 bp) was used as a low-copy gene. The DNA ladder used was the GeneRuler 100-bp Plus DNA ladder (Fermentas).
Nevertheless, the exact mechanism of cell and tissue lysis and the capture of intact DNA is obfuscated by intellectual property concerns.

At present, there is no evidence for the use of an FTA-based strategy in molecular plant nematology. In general, plant-parasitic nematodes are multicellular organisms that possess a complex anatomical organization (12). Their surface layer, known as the cuticle, has been shown to be highly resistant to chemical and mechanical disruption (3). For this reason, most conventional techniques for the preparation of nucleic acids from these nematodes use various combinations of mechanical (hand homogenization, freezing in liquid nitrogen, and so on) and chemical or biochemical (detergents, proteinase $\mathrm{K}$, and so on) disruption. We were surprised to discover that the FTA technology shown here was fully functional for the sampling and analysis of the tested phytonematode species (Figs. 2 to 6). We found that the FTAbased approach was comparable with conventional organic chemical-based DNA purification procedures, if not more efficient, as measured by the reliability of the PCR assays (Figs. 2 to 4). In addition, we demonstrated that the FTA methodology provided more consistent results when a target low-copy gene was analyzed (Fig. 5B).

These findings open the door for new methods of experimental research and DNA diagnostics involving plant-parasitic nematodes. Such FTA-based assays are not time consuming and are based on nontoxic aqueous solutions, unlike other conventional DNA purification methods that utilize toxic reagents. This significantly simplifies field sampling and the genomic analysis of plant-parasitic nematodes and reduces the health hazards faced by laboratory personnel.

Among other exciting findings, we demonstrated that the FTAcaptured nematode samples could be archived for many years at room temperature without an observable decrease in the anchored DNA molecules. In our long-term experiment, we sampled $D$. dipsaci specimens either in the form of individual nematodes or from the mechanical printing of nematode-infested plant tissues; these FTA cards were stored at laboratory temperatures for 7 years. After this period, we purified the DNA using the FTA protocol and performed PCR amplification of the selected genes. Both the high-copy ITS-rDNA gene region and the low-copy SCAR marker gene were successfully amplified and detected (Fig. 6B). We predict that the FTA-captured samples can be practically stored for far beyond the 7-year period tested in our experiment. This would be highly valuable for molecular plant nematology research, phytosanitary diagnostics, and plant breeding technologies, because it significantly reduces the energy-consuming storage of nematode samples in freezers and refrigerators.

Together, our data show that the FTA-based technology is a promising, highly reliable tool for the collection, storage, and DNA-based analysis of plant-parasitic nematodes.

\section{ACKNOWLEDGMENTS}

This research was financed by a research grant from the Ministry of Agriculture of The Czech Republic (MZE-QF4156) and by a research grant from the Ministry of Education of The Czech Republic (MSM-604607901).

\section{LITERATURE CITED}

1. Ahmed, H. A., MacLeod, E. T., Hide, G., Welburn, S. C., and Picozzi, K. 2011. The best practice for preparation of samples from FTA cards for diagnosis of blood borne infections using African trypanosomes as a model system. Parasites \& Vectors 4:68.

2. Allgeier, L., Hemenway, J., Shirley, N., Lanier, T., and Coyle, H. M. 2011. Field testing of collection cards for Cannabis sativa samples with a single hexanucleotide DNA marker. J. Forensic Sci. 56:1245-1249.

3. Davies, K. G., and Curtis, R. H. C. 2011. Cuticle surface coat of plantparasitic nematodes. Annu. Rev. Phytopathol. 49:135-156.

4. De Bie, R. P., Schmeink, C. E., Bakkers, J. M. J. E., Snijders, P. J. F., Quint, W. G. V., Massuger, L. F. A. G., Bekkers, R. L. M., and Melchers, 
W. J. G. 2011. The indicating FTA elute cartridge: A solid sample carrier to detect high-risk HPV and high-grade cervical lesions. J. Mol. Diagn. 13:371-376.

5. Douda, O., Marek, M., Zouhar, M., and Rysanek, P. 2013. Insights into the structure and phylogeny of the 28S rRNA expansion segments D2 and D3 of the plant-infecting nematodes from the genus Ditylenchus (Nematoda: Anguinidae). Phytopathol. Mediterr. 52:84-97.

6. Eamsobhana, P., Lim, P. E., Solano, G., Zhang, H., Gan, X., and Yong, H. S. 2010. Molecular differentiation of Angiostrongylus taxa (Nematoda: Angiostrongylidae) by cytochrome c oxidase subunit I (COI) gene sequences. Acta Trop. 116:152-156.

7. Ellis, R. E., Sulston, J. E., and Coulson, A. R. 1986. The rDNA of $C$. elegans: Sequence and structure. Nucleic Acids Res. 14:2345-2364.

8. Green, J., Wang, D., Lilley, C. J., Urwin, P. E., and Atkinson, H. J. 2012. Transgenic potatoes for potato cyst nematode control can replace pesticide use without impact on soil quality. PLoS One 7:e30973.

9. Grund, E., Darissa, O., and Adam, G. 2010. Application of FTA cards to sample microbial plant pathogens for PCR and RT-PCR. J. Phytopathol. 158:750-757.

10. Hu, M. X., Zhuo, K., and Liao, J. L. 2011. Multiplex PCR for the simultaneous identification and detection of Meloidogyne incognita, M. enterolobii, and $M$. javanica using DNA extracted directly from individual galls. Phytopathology 101:1270-1277.

11. Kikuchi, T., Cotton, J. A., Dalzell, J. J., Hasegawa, K., Kanzaki, N., McVeigh, P., Takanashi, T., Tsai, I. J., Assefa, S. A., Cock, P. J. A., Da Otto, T., Hunt, M., Reid, A. J., Sanchez-Flores, A., Tsuchihara, K., Yokoi, T., Larsson, M. C., Miwa, J., Maule, A. G., Sahashi, N., Jones, J. T., and Berriman, M. 2011. Genomic insights into the origin of parasitism in the emerging plant pathogen Bursaphelenchus xylophilus. PLoS Pathog. 7:e1002219.

12. Krusberg, L. R. 1962. Biology of plant-parasitic nematodes. J. Parasitol. 48:826-829.

13. Lin, J. J., Fleming, R., Kuo, J., Matthews, B. F., and Saunders, J. A. 2000. Detection of plant genes using a rapid, nonorganic DNA purification method. BioTechniques 28:346-350.

14. Liu, S., Kandoth, P. K., Warren, S. D., Yeckel, G., Heinz, R., Alden, J., Yang, C., Jamai, A., El-Mellouki, T., Juvale, P. S., Hill, J., Baum, T. J., Cianzio, S., Whitham, S. A., Korkin, D., Mitchum, M. G., and Meksem, K. 2012. A soybean cyst nematode resistance gene points to a new mechanism of plant resistance to pathogens. Nature 492:256-260.

15. Marek, M., Zouhar, M., Douda, O., Gaar, V., and Ryšánek, P. 2013. Comparative molecular analysis of Bursaphelenchus vallesianus, a woodinhabiting nematode isolated from declining pine trees in the Czech
Republic. Plant Pathol. Online publication. doi:10.1111/ppa.12071

16. Marek, M., Zouhar, M., Douda, O., Mazakova, J., and Rysanek, P. 2010. Bioinformatics-assisted characterization of the ITS1-5.8S-ITS2 segments of nuclear rRNA gene clusters, and its exploitation in molecular diagnostics of European crop-parasitic nematodes of the genus Ditylenchus. Plant Pathol. 59:931-943.

17. Marek, M., Zouhar, M., Rysanek, P., and Havranek, P. 2005. Analysis of ITS sequences of nuclear rDNA and development of a PCR-based assay for the rapid identification of the stem nematode Ditylenchus dipsaci (Nematoda: Anguinidae) in plant tissues. Helminthologia 42:49-56.

18. Maroteaux, L., Herzog, M., and Soyer-Gobillard, M. O. 1985. Molecular organization of dinoflagellate ribosomal DNA: Evolutionary implications of the deduced 5.8 S rRNA secondary structure. BioSystems 18:307-319.

19. McK Bird, D., Williamson, V. M., Abad, P., McCarter, J., Danchin, E. G. J., Castagnone-Sereno, P., and Opperman, C. H. 2009. The genomes of root-knot nematodes. Annu. Rev. Phytopathol. 47:333-351.

20. Ndunguru, J., Taylor, N. J., Yadav, J., Aly, H., Legg, J. P., Aveling, T., Thompson, G., and Fauquet, C. M. 2005. Application of FTA technology for sampling, recovery and molecular characterization of viral pathogens and virus-derived transgenes from plant tissues. Virol. J. 2.

21. Opperman, C. H., Bird, D. M., and Schaff, J. E. 2009. Genomic analysis of the root-knot nematode genome. Plant Cell Monogr. 15:221-237.

22. Osman, F., and Rowhani, A. 2006. Application of a spotting sample preparation technique for the detection of pathogens in woody plants by RT-PCR and real-time PCR (TaqMan). J. Virol. Methods 133:130-136.

23. Reid, A. 2009. PCR detection of potato cyst nematode. Methods Mol. Biol. 508:289-294.

24. Sultana, T., Kim, J., Lee, S. H., Han, H., Kim, S., Min, G. S., Nadler, S. A., and Park, J. K. 2013. Comparative analysis of complete mitochondrial genome sequences confirms independent origins of plant-parasitic nematodes. BMC Evol. Biol. 12.

25. Xue, B., Hamamouch, N., Li, C., Huang, G., Hussey, R. S., Baum, T. J., and Davis, E. L. 2013. The 8D05 parasitism gene of Meloidogyne incognita is required for successful infection of host roots. Phytopathology 103:175-181.

26. Zouhar, M., Marek, M., Douda, O., Mazakova, J., and Rysanek, P. 2007. Conversion of sequence-characterized amplified region (SCAR) bands into high-throughput DNA markers based on RAPD technique for detection of the stem nematode Ditylenchus dipsaci in crucial plant hosts. Plant Soil Environ. 53:97-104.

27. Zouhar, M., Rysanek, P., and Tesarova, B. 2003. Occurrence of the rootknot nematode Meloidogyne hapla in the Czech Republic. Plant Dis. $87: 98$ 